\title{
KEDUDUKAN ALAT BUKTI TULISAN TERHADAP PENYELESAIAN PERKARA DI PENGADILAN
}

\author{
Rosdalina Bukido*
}

\begin{abstract}
Abstrak
Pembuktian merupakan salah satu aspek yang sangat penting didatangkan dan disiapkan oleh para pihak (Penggugat dan Tergugat) dalam membuktikan kebenaran suatu peristiwa hukum. Ada bermacam-macam alat bukti yang ada pada proses pembuktian dalam hukum acara perdata yang salah satu di antaranya adalah alat bukti tulisan/surat. Alat bukti ini menempati posisi yang pertama bagi hakim dalam menilai suatu peristiwa hukum yang terjadi di antara para pihak. Alat bukti tulisan mempunyai kekuatan pembuktian yang sempurna jika akta tersebut memenuhi syarat otentisitas yang ditentukan oleh undang-undang, salah satunya harus dibuat oleh atau di hadapan pejabat yang berwenang. Jika persyaratan yang ditentukan oleh undang-undang itu dipenuhi oleh para pihak maka kekuatan hukum pembuktian itu (alat bukti tulisan) sangat menjadi pertimbangan utama hakim dalam mengambil keputusan yang berkaitan dengan pokok perkara yang disidangkan.
\end{abstract}

Kata kunci : Alat bukti, akta otentik, penyelesaian perkara

\section{A. Latar Belakang Masalah}

Dalam suatu proses perdata, salah satu tugas hakim adalah untuk menyelidiki apakah suatu hubungan hukum yang menjadi dasar gugatan benar-benar ada atau tidak. ${ }^{1}$ Adanya hubungan hukum inilah yang harus terbukti apabila penggugat menginginkan kemenangan dalam suatu perkara. Apabila penggugat tidak berhasil untuk membuktikan dalil-dalilnya yang

\footnotetext{
* Penulis adalah dosen tetap pada jurusan Syari'ah STAIN Manado, alumni Program Pascasarjana Universitas Gadjah Mada (UGM) Yogyakarta Program Studi Ilmu Hukum Konsentrasi Hukum Perdata

${ }^{1}$ Retnowulan Sutantio, Iskandar Oeripkartawinata, Hukum Acara Perdata dalam Teori dan Praktek, (Bandung: CV. Mandar Maju, 1997), h. 58
} 
menjadi dasar gugatannya, maka gugatannya akan ditolak, sedangkan apabila berhasil, maka gugatannya akan dikabulkan.

Alat bukti yang didatangkan oleh para pihak di pengadilan bermacammacam di antaranya alat bukti tulisan, keterangan saksi, persangkaan, pengakuan dan sumpah. Dari kelima alat bukti tersebut, alat bukti tulisan menempati urutan pertama yang menjadi penilaian hakim dalam menyelidiki suatu proses perkara yang nantinya menjadi bahan pertimbangan untuk dijatuhkannya sebuah putusan.

Alat bukti tulisan merupakan aspek yang sangat penting pada tahap pembuktian dalam penyelesaian perkara di pengadilan. Sebelum hakim (majelis hakim) mengambil keputusan terhadap sebuah kasus di pengadilan mereka harus mempertimbangkan alat-alat bukti yang dikemukakan oleh para pihak. Menurut pasal $1866 \mathrm{KUH}$ Perdata dijelaskan bahwa alat bukti terdiri atas bukti tulisan, bukti dengan saksi-saksi, persangkaan-persangkaan, pengakuan dan sumpah. ${ }^{2}$

Pembuktian dengan tulisan dilakukan dengan tulisan-tulisan otentik maupun dengan tulisan di bawah tangan. Pada pasal 1866 KUH Perdata tersebut dikemukakan bahwa urutan pertama alat bukti itu adalah bukti tulisan. Hal ini jelas bahwa alat bukti tulisan itu merupakan alat bukti utama dan paling penting pada tahap pembuktian di pengadilan.

Bukti dalam pengertian sehari-hari adalah segala hal yang dipergunakan untuk meyakinkan pihak lain yang dapat dikatakan macamnya

\footnotetext{
${ }^{2}$ R. Subekti, Kitab Undang-undang Hukum Perdata, (Jakarta: Pradnya Paramita, 2006), h.
} 
tidak terbatas asalkan bukti tersebut bisa meyakinkan pihak lain tentang pendapat, peristiwa, dan keadaan. Tetapi Pengertian bukti menurut hukum adalah sudah ditentukan menurut undang-undang.

Dalam hukum acara perdata, penyebutan alat bukti tertulis (surat) merupakan alat bukti yang utama, karena surat justeru dibuat untuk membuktikan suatu keadaan, atau kejadian yang telah terjadi atau perbuatan hukum yang harus dilakukan oleh seseorang nantinya.

Di Pengadilan Agama Manado misalnya yang menyidangkan perkara perkawinan, kewarisan, wasiat, hibah, wakaf, zakat, infaq, shadaqah dan ekonomi syari'ah, para pihak setelah sampai pada tahap pembuktian hakim memberikan kesempatan yang seluas-luasnya untuk mendatangkan alat bukti yang bertujuan untuk memperkuat tuntutan mereka. Pihak Penggugat dan Tergugat berusaha meyakinkan hakim bahwa apa yang mereka kemukakan adalah benar, tentunya untuk mendukung pernyataan tersebut harus didukung oleh pembuktian yang sah.

Bentuk alat bukti yang didatangkan oleh para pihak berbeda-beda tergantung pada pokok perkara yang masing-masing pihak tuntut di persidangan. Oleh karena banyaknya alat bukti dalam tahap pembuktian ini dan semakin kompleksnya perkembangan hukum dewasa ini memotivasi penulis untuk menelaah lebih lanjut tentang Kedudukan Alat Bukti Tertulis Terhadap Penyelesaian Perkara Di Pengadilan. 


\section{B. Pembahasan}

1. Pengertian pembuktian dan alat bukti

Hukum pembuktian merupakan bagian daripada hukum acara dan memuat selain aturan-aturan tata tertib cara bagaimana kedua pihak berperkara, harus bertindak dalam saling tukar menuar konklusi/kesimpulan dan mengajukan bahan-bahan bukti untuk menguatkan kebenaran pendiriannya masing-masing, memuat juga aturan cara bagaimana hakim harus bertindak dalam meneliti apakah hubungan hukum yang diperselisihkan kedua pihak dalam perkara itu berdasarkan dalil-dalil dan bahan bukti yang mereka ajukan benar-benar ada atau tidak untuk kemudian dapat menetapkan pihak manakah yang dianggap berhasil dalam membuktikan kebenaran pendiriannya. ${ }^{3}$

Dilihat dari pihak-pihak yang berperkara, maka alat bukti dapat diartikan sebagai alat atau upaya yang bisa digunakan oleh pihak-pihak yang berperkara untuk meyakinkan hakim di muka pengadilan. Sedangkan jika dilihat dari segi pengadilan yang memeriksa perkara alat bukti artinya alat atau upaya yang bisa digunakan oleh hakim untuk memutus perkara. Jadi, alat bukti tersebut diperlukan oleh pencari keadilan dan juga oleh pengadilan. $^{4}$

Suatu persengketaan atau perkara tidak bisa diselesaikan tanpa adanya alat bukti, artinya kalau gugatan penggugat tidak berdasarkan bukti maka

\footnotetext{
${ }^{3}$ H.M. Abdurrahman, Hukum Acara Perdata, (cet. IV, Jakarta: Universitas Trisakti), h. 71

${ }^{4}$ A. Roihan A. Rasyid, Hukum Acara Peradilan Agama, (Jakarta: PT. Raja Grafindo Persada, 1998), h. 144
} 
perkara tersebut akan diputus juga oleh hakim tetapi dengan menolak gugatan karena tidak terbukti.

2. Pengertian tulisan dari segi yuridis

Tulisan ditinjau dari segi yuridis dalam kaitannya dengan alat bukti ditinjau dari berbagai aspek.

a). Tanda bacaan, berupa aksara

Tulisan atau surat terdiri dari tanda bacaan dalam bentuk aksara. Tidak dipersoalkan aksaranya. Boleh aksara Latin, Arab Cina, dsb. Boleh juga aksara lokal seperti Bugis, Jawa, dan Batak. Semua diakui dan sah sebagai aksara yang berfungsi sebagai tanda bacaan untuk mewujud bentuk tulisan atau surat sebagai alat bukti.

b). Disusun berupa kalimat sebagai pernyataan

Agar aksara tersebut dapat berbentuk menjadi tulisan atau surat maupun akta, harus disusun berbentuk kalimat sebagai ekspresi atau pernyataan cetusan pikiran atau kehendak orang yang menginginkan pembuatannya. Rangkaian kalimat itu sedemikian rupa susunan dan isinya, dapat dimengerti dengan jelas oleh orang yang membacanya sesuai dengan apa yang dikehendaki dalam surat itu.

c). Ditulis pada bahan tulisan

Pada umumnya ditulis di kertas. Dapat juga pada bahan lain misalnya kulit kayu, bambu atau kain, dll. Dalam hukum bukan hanya tulisan yang dituangkan dalam kertas saja yang dapat dijadikan alat bukti dalam berperkara, tetapi tulisan yang tercantum pada bahan di luar kertas. 
d). Ditanda tangani pihak yang membuat

Suatu surat atau tulisan yang memuat pernyataan atau kesepakatan yang jelas dan terang, tetapi tidak ditandatangani ditinjau dari segi hukum pembuktian tidak sempurna sebagai surat atau akta sehingga tidak sah digunakan sebagai alat bukti tulisan. ${ }^{5}$

e). Mencantumkan tanggal

Surat yang dianggap sempurna bernilai sebagai alat bukti tulisan atau akta, selain terdapat tanda tangan juga harus mencantumkan tanggal penandatanganannya. Meskipun secara yuridis surat yang tidak bertanggal tidak hilang fungsinya sebagai alat bukti, namun hal itu dapat dianggap sebagai cacat yang melemahkan eksistensinya sebagai alat bukti, sebab tanpa tanggal sulit menentukan kepastian pembuatan dan penandatanganannya sehingga memberi peluang besar bagi pihak lawan untuk menyangkal kebenaran pembuatannya.

3. Pengertian tanda tangan menurut hukum

Fungsi tanda tangan dalam suatu surat tidak lain daripada memastikan identifikasi atau menentukan kebenaran ciri-ciri penanda tangan. Bentuk tanda tangan yang dibenarkan menurut hukum adalah :

- Menuliskan nama penanda tangan dengan atau tanpa menambah nama kecil

- Tanda tangan dengan cara menuliskan nama kecil

${ }^{5}$ M. Yahya Harahap, Hukum Acara Perdata, (Cet. Ketiga, Jakarta: Sinar Grafika, 2005), h. 560 
- Ditulis tangan oleh penanda tangan, tidak dibenarkan dengan stempel dengan huruf cetak

- Dibenarkan mencantumkan kopi tanda tangan si penanda tangan dengan syarat :

Orang yang mencantum kopi itu berwenang untuk itu dalam hal ini orang yang bersangkutan sendiri

Orang yang mendapat kuasa atau mandat dari pemilik tanda tangan.

- Dapat juga mencantumkan tanda tangan dengan mempergunakan karbon.

4. Alat bukti surat atau tulisan

Surat merupakan alat bukti tertulis yang memuat tulisan untuk menyatakan pikiran seseorang sebagai alat bukti. Menurut bentuknya alat bukti tertulis diklasifikasikan dua jenis lagi, yaitu surat akta dan bukan surat akta. ${ }^{6}$ Surat akta adalah surat yang bertanggal dan diberi tanda tangan, yang memuat peristiwa-peristiwa yang menjadi dasar suatu hak atau perikatan yang digunakan untuk pembuktian. Surat akta diklasifikasikan lagi menjadi dua jenis yaitu surat akta otentik dan surat bukan akta otentik (di bawah tangan).

Alat bukti surat atau tulisan adalah segala sesuatu yang memuat tandatanda bacaan yang dimaksudkan untuk menyampaikan buah pikiran seseorang dan digunakan sebagai pembuktian. Dengan demikian maka segala sesuatu yang tidak memuat tanda-tanda bacaan, atau meskipun

${ }^{6}$ Abdulkadir Muhammad, Hukum Acara Perdata Indonesia, (Cet. VII, Bandung: PT. Citra Aditya Bakti, 2000), h. 119 
memuat tanda-tanda bacaan akan tetapi tidak mengandung buah pikiran, bukanlah termasuk alat bukti tertulis atau surat-surat.

Al-Qur'an memerintahkan untuk menuliskan transaksi bidang muamalah yang tidak tunai. Rasulullah membuat perjanjian Hudaibiyah, perjanjian antara kaum muslimin dan musyrikin Mekah juga tertulis. Sampainya AlQur'an dan Hadits kepada kita semua, yang justru merupakan sumber dan pegangan pokok bagi ajaran Islam tidak lain melalui tulisan. Jadi sangatlah logis kalau tulisan atau surat-surat dijadikan sebagai alat bukti.

\section{Akta Otentik (AO)}

Menurut kamus hukum akta otentik adalah suatu akta yang dibuat di dalam bentuk yang ditentukan oleh undang-undang, dibuat oleh atau di hadapan pegawai-pegawai umum yang berkuasa untuk itu ditempat dimana akte dibuatnya. ${ }^{7}$ Akta otentik adalah akta yang dibuat oleh atau di hadapan pejabat yang berwenang untuk itu, menurut ketentuan tertentu yang telah ditetapkan. ${ }^{8}$ Sebagai pejabat yang berwenang dimaksudkan antara lain Notaris, Juru Sita, Panitera, Hakim Pengadilan, Pegawai Catatan Sipil, Pegawai Pencatat Nikah (PPN), Pejabat Pembuat Akta Tanah (PPAT), Pejabat Pembuat Akta Ikrar Waqaf (PPAIW), dan lainlain.

7 J.C.T. Simorangkir, Rudy T. Erwin, J.T. Prasetyo, Kamus Hukum, (Cet. VII, Jakarta: Sinar Grafika, 2002), h. 6

${ }^{8}$ Sudikno Mertousumo, Hukum Acara Perdata Indonesia, (Yogyakarta: Liberty, 1988), h. 116 
Adapun pengertian pejabat yang berwenang contohnya Kepala KUA Kecamatan, Kepala PPN, PPAIW. Jika surat nikah dikeluarkan oleh Kepala KUA (tanpa menyebutkan sebagai Kepala PPN), maka surat nikah itu tidak bisa dikatakan Akta Nikah Otentik sebab Kepala KUA saja bukanlah pejabat yang berwenang yang membuat dan mengeluarkan Akta Nikah bagi yang beragama Islam. Surat jual beli tanah yang dibuat oleh Camat tanpa menyebutkan ia sebagai PPAT maka surat jual beli tanah tersebut bukanlah akta otentik.

Sebuah akta otentik yaitu yang dibuat dengan bentuk yang sesuai dengan undang-undang oleh atau di hadapan pejabat umum yang berwenang di tempat akta itu dibuat, merupakan bukti lengkap antara para pihak serta keturunannya dan mereka yang mendapatkan hak tentang apa yang dimuat di dalamnya dan bahkan tentang suatu pernyataan belaka, hal terakhir ini sepanjang pernyataan itu ada hubungan langsung dengan apa yang menjadi pokok akta itu. ${ }^{9}$

Akta Otentik sebagai Alat Bukti yang Sempurna. Pembuktian dalam hukum acara mempunyai arti yuridis berarti hanya berlaku bagi pihak-pihak yang berperkara atau yang memperoleh hak dari mereka dan tujuan dari pembuktian ini adalah untuk memberi kepastian kepada Hakim tentang adanya suatu peristiwa-peristiwa tertentu. Maka pembuktian harus dilakukan oleh para pihak dan siapa yang harus membuktikan atau yang disebut juga sebagai beban pembuktian

\footnotetext{
${ }^{9}$ Ropaun Rambe, Hukum Acara Perdata Lengkap, (Cet. IV, Jakarta: Sinar Grafika), h. 234
} 
berdasarkan pasal 163 HIR ditentukan bahwa barang siapa yang menyatakan ia mempunyai hak atau ia menyebutkan sesuatu perbuatan untuk menguatkan haknya itu atau untuk membantah hak orang lain, maka orang itu harus membuktikan adanya hak itu atau adanya kejadian itu. ${ }^{10}$ Ini berarti dapat ditarik kesimpulan bahwa siapa yang mendalilkan sesuatu maka ia yang harus membuktikan.

Menurut sistem dari HIR hakim hanya dapat mendasarkan putusannya atas alat-alat bukti yang sudah ditentukan oleh Undang-Undang. Untuk dapat membuktikan adanya suatu perbuatan hukum, maka diperlukan alat bukti yang mempunyai kekuatan pembuktian. Dalam hal ini agar akta sebagai alat bukti tulisan mempunyai kekuatan pembuktian yang sempurna, maka akta tersebut harus memenuhi syarat otentisitas yang ditentukan oleh undang-undang, salah satunya harus dibuat oleh atau dihadapan pejabat yang berwenang.

Dalam hal harus dibuat oleh atau dihadapan pejabat yang berwenang inilah profesi Notaris memegang peranan yang sangat penting dalam rangka pemenuhan syarat otentisitas suatu surat atau akta agar mempunyai kekuatan pembuktian yang sempurna karena berdasarkan pasal 1 UUJN Notaris adalah pejabat umum yang berwenang untuk membuat akta otentik.

Akta otentik merupakan alat bukti yang sempurna, sebagaimana dimaksud

10 R. Soesilo, RIB/HIR dengan Penjelasan lengkap disertai Undang-undang/Peraturanperaturan: Hukum Acara Perdata-Hukum Acara Pidana Peradilan Umum, (Bandung : PT. Karya Nusantara, 1989), h. 119 
dalam pasal 1870 KUHPerdata. Akta otentik memberikan diantara para pihak termasuk para ahli warisnya atau orang yang mendapat hak dari para pihak itu suatu bukti yang sempurna tentang apa yang diperbuat/ dinyatakan di dalam akta.

Kekuatan pembuktian sempurna yang terdapat dalam suatu akta otentik merupakan perpaduan dari beberapa kekuatan pembuktian dan persyaratan yang terdapat padanya. Ketiadaan salah satu kekuatan pembuktian ataupun persyaratan tersebut akan mengakibatkan suatu akta otentik tidak mempunyai nilai kekuatan pembuktian yang sempurna (volledig) dan mengikat (bindende) sehingga akta akan kehilangan keotentikannya.

Kekuatan pembuktian suatu akta otentik menurut sifatnya dapat dibagi menjadi dua yaitu:

1. Kekuatan pembuktian formal yaitu bahwa kedua belah pihak benarbenar sudah menerangan di muka notaris apa yang telah tertulis di dalam akta itu.

2. Kekuatan pembutian material yaitu bahwa apa yang telah diterangkan oleh kedua pihak di muka notaris dan tertulis dalam akta itu, memang benar-benar terjadi atau dalam kata-kata lain bahwa isinya keterangan mereka itu benar-benar terjadi.

Bagi akta otentik "tanda tangan dan tanggal pembuatan akta" telah cukup terbukti dengan diajukannya akta itu dan siapa yang menantangnya harus membuktikan kebenaran dalil-dalilnya. 
6. Akta di bawah tangan

Sebagaimana telah diketahui bersama bahwa kekuatan pembuktian yang "sempurna" mempunyai arti bahwa isi akta itu oleh hakim dianggap benar sampai ada bukti lawan yang melumpuhkan isi akta tersebut, misalnya pihak lawan mengakui kebenaran adanya perjanjian seperti dimuat dalam akta, akan tetapi ia sudah memenuhi isi perjanjian itu, sehingga perjanjian itu sudah tidak berlaku lagi. Perlawanan yang sedemikian itu dapat melumpuhkan tuntutan penggugat yang didasarkan atas perjanjian dalam kata tersebut, apabila pihak pelawan/tergugat dapat membuktikan kebenarannya.

Akta di bawah tangan atau akta bukan otentik ialah segala tulisan yang memang sengaja dibuat untuk dijadikan bukti tetapi tidak dibuat di hadapan atau oleh pejabat yang berwenang untuk itu dan bentuknya pun tidaklah terikat kepada bentuk tertentu. Dengan demikian, akta selain otentik semuanya termasuk akta di bawah tangan. Misalnya surat jual beli tanah yang dibuat oleh kedua belah pihak, sekalipun di atas kertas segel dan ditandatangani oleh ketua RT, ketua RW, Lurah/Kepala Desa, tidak bisa disebut akta otentik karena pejabat yang berwenang membuat akta tanah yaitu PPAT, hanyalah Notaris dan Camat.

Kekuatan akta di bawah tangan, hakim menilainya bebas, akan tetapi jika akta yang bersifat dibuat oleh kedua belah pihak, seperti jual beli tanah yang bukan otentik, apabila tanda tangan yang tercantum di dalamnya diakui oleh pihak yang menandatanganinya maka akta tersebut 
mempunyai kekuatan sama dengan akta otentik, tetapi masih mempunyai perbedaan dengan akta otentik. ${ }^{11}$

Akta otentik berlaku bagi kedua belah pihak, bagi pihak ketiga dan bagi siapapun juga, sedangkan akta di bawah tangan tadi hanya berlaku bagi kedua belah pihak, bagi ahli warisnya dan bagi orang yang memperoleh hak daripadanya, tidak untuk pihak ketiga dan semua orang lainnya.

7. Syarat-syarat alat bukti tulisan

Syarat formil bukti akta otentik bersifat partai yang dibuat oleh para pihak di hadapan pejabat:

- Dibuat di hadapan pejabat yang berwenang menurut undang-undang;

- Dihadiri oleh para pihak;

- Kedua piha dikenal atau dikenalkan kepada pejabat;

- Dihadiri oleh dua orang saksi;

- Menyebut identitas notaris atau pejabat;

- Menyebut tempat, hari, tanggal, bulan dan tahun pembuatan akta;

- Notaris membacakan akta di hadapan para penghadap;

- Ditanda tangani semua pihak;

- Penegasan pembacaan, penerjemahan dan penandatanganan pada bagian penutup akta.

Syarat formil bukti otentik yang dibuat oleh pejabat yang berwenang:

- Dibuat dan ditandatangani oleh pejabat yang berwenang;

\footnotetext{
${ }^{11}$ R. Subekti, Hukum Pembuktian, (Jakarta: Pradnya Paramita, 1975), h. 29-30
} 
- Menyebut identitas, tempat, hari, tanggal, bulan dan tahun pembuatan akta;

- Bentuk akta dibuat sesuai dengan ketentuan peraturan perundangundangan yang berlaku.

Adapun syarat materiil bukti akta otentik:

- Berisi keterangan kesepakatan para pihak;

- Berisi keterangan perbuatan atau hubungan hukum;

- Pembuatan akta sengaja dimaksudkan sebagai bukti;

- Tidak bertentangan dengan peraturan perundang-undangan, agama, kesusilaan, dan ketertiban umum;

- Bermaterai.

Sedang kekuatan hukum bukti surat otentik:

- Sempurna dan mengikat sepanjang tidak dibuktikan oleh pihak lawan bahwa surat otentik tersebut palsu atau cacat;

- Kepalsuan meliputi:

1. Kepalsuan karena berlawanan dengan kenyataan sebenarnya;

2. Kepalsuan tanda tangan;

3. Kepalsuan ada penghapusan isi;

4. Kepalsuan mengandung penambahan/pengurangan;

5. Penyalahgunaan tanda tangan di bawah blangko kosong. 
- Alat bukti yang dapat diajukan lawan untuk melumpuhkan alat bukti akta otentik dapat berupa alat bukti apa saja seperti, akta otentik, akta di bawah tangan, saksi, persangkaan dan sumpah.

- Bukti otentik mengandung cacat jika akta tersebut tidak memenuhi syarat formil dan materiil. ${ }^{12}$

8. Macam-macam bukti di bawah tangan

Dasar hukum akta di bawah tangan pasal 286-305 Rbg, pasal 1874, 1878 KUHPerdata.

Ada dua macam akta di bawah tangan yaitu:

- Akta di bawah tangan yang bersifat partai

- Akta di bawah tangan yang bersifat sepihak

Syarat formil bukti akta di bawah tangan yang bersifat partai:

- Berbentuk tulisan

- Dibuat secara partai tanpa bantuan atau di hadapan pejabat yang berwenang menurut undang-undang

- Ditandatangani oleh para pihak

- Mencantumkan hari, tanggal, bulan, tahun dan tempat penandatanganan

- Bermaterai.

Syarat materiil bukti akta di bawah tangan yang bersifat partai:

${ }^{12}$ Edi Riadi, Hukum Acara Peradilan Agama - Makalah disampaikan dalam acara orientasi pemberkasan perkara peradilan agama se wilayah PTA Pekanbaru tanggal 24 Juni 2010 di Pekanbaru, h. 45 
- Keterangan yang tercantum dalam akta di bawah tangan berisi persetujuan mengenai perbuatan hukum (contoh: pemberian uang nafkah, penyerahan barang) atau hubungan hukum (contoh: sewa menyewa)

- Sengaja dibuat sebagai alat bukti.

Syarat formil bukti akta di bawah tangan yang bersifat sepihak:

- Berbentuk tertulis

- Dibuat sendiri oleh yang bersangkutan

- Ditandatangani oleh pembuatnya

- Mencantumkan tempat, hari, tanggal, bulan dan tahun pembuatan

- Bermaterai.

Syarat materiil bukti akta di bawah tangan yang bersifat sepihak:

- Keterangan yang tercantum dalam akta di bawah tangan berisi persetujuan mengenai perbuatan hukum (contoh: pemberian uang nafkah, penyerahan barang) atau hubungan hukum (contoh: sewa menyewa).

- Sengaja dibuat sebagai alat bukti.

Kekuatan hukum bukti akta di bawah tangan :

- Isi yang tercantum dalam akta dianggap benar.

- Memiliki daya memikat kepada ahli waris dan orang yang mendapat hak dari padanya. 
- Pihak lawan dapat melumpuhkan bukti akta di bawah tangan dengan alat bukti lainnya.

\section{Kesimpulan}

Para pihak yang berperkara di pengadilan yang telah sampai pada tahap pembuktian kedudukan alat bukti tulisan merupakan alat bukti yang paling sempurna yang bertujuan memberikan kepastian hukum kepada hakim tentang peristiwa yang terjadi. Alat bukti tulisan mempunyai kekuatan pembuktian yang sempurna, oleh karena itu akta tersebut harus memenuhi syarat otentisitas yang ditentukan oleh undang-undang, salah satunya harus dibuat oleh atau di hadapan pejabat yang berwenang. Jika persyaratan yang ditentukan oleh undang-undang itu dipenuhi maka kekuatan hukum pembuktian itu sangat menjadi pertimbangan utama hakim dalam mengambil keputusan yang berkaitan dengan pokok perkara yang disidangkan. 


\section{Daftar Kepustakaan}

Andi Tahir Hamid, 1996, Peradilan Agama dan Bidangnya, Jakarta: Sinar Grafika

Abdulkadir Muhammad, 2000, Hukum Acara Perdata Indonesia, Cet. VII, Bandung: PT. Citra Aditya Bakti

A. Roihan A. Rasyid, 1998, Hukum Acara Peradilan Agama, Jakarta: PT. Raja Grafindo Persada.

Edi Riadi, Hukum Acara Peradilan Agama - Makalah disampaikan dalam acara orientasi pemberkasan perkara peradilan agama se wilayah PTA Pekanbaru tanggal 24 Juni 2010 di Pekanbaru

H.M. Abdurrahman, 2003, Hukum Acara Perdata, Cet. IV, Jakarta:Universitas Trisakti

J.C.T. Simorangkir, Rudy T. Erwin, J.T. Prasetyo, 2002, Kamus Hukum, Cet. VII, Jakarta: Sinar Grafika

M. Yahya Harahap, 2005, Hukum Acara Perdata, Cet. Ketiga, Jakarta: Sinar Grafika.

Retnowulan Sutantio, Iskandar Oeripkartawinata, 1997, Hukum Acara Perdata dalam Teori dan Praktek, Cet. VIII, Bandung: CV. Mandar Maju

R. Subekti, 1975, Hukum Pembuktian, Jakarta: Pradnya Paramita.

Ropaun Rambe, 2003, Hukum Acara Perdata Lengkap, Cet. IV, Jakarta: Sinar Grafika.

R. Subekti, 1999, Kitab Undang-undang Hukum Perdata, Jakarta: Pradnya Paramita.

R. Soesilo, 1989, RIB/HIR dengan Penjelasan (lengkap disertai Undangundang/Peraturan-peraturan: Hukum Acara Perdata - Hukum Acara Pidana Peradilan Umum, Bandung : PT. Karya Nusantara.

R. Tresna, 2005, Komentar HIR, Cet. XVIII, Jakarta: PT. Pradnya Paramita.

Sudikno Mertousumo, 1988, Hukum Acara Perdata Indonesia, Yogyakarta: Liberty.

Undang-undang Peradilan Agama - UU Republik Indonesia Nomor 2 Tahun 2006, Indonesia Legal Center Publishing.

Yahya Harahap, 1993, Ruang Lingkup Permasalahan Eksekusi Bidang Perdata, Cet. IV, Jakarta: PT. Gramedia Pustaka Utama. 